\title{
Sunkist Peel Ethanol Extract Ameliorates Diabetic Nephropathy in Streptozotocin-Induced Diabetic Wistar Rats
}

\author{
Maya Sari Mutia*(D), Chrismis Novalinda Ginting (D), Ok YulizaliD \\ Department of Histology, Faculty of Medicine, Universitas Prima Indonesia, Medan, North Sumatera, Indonesia
}

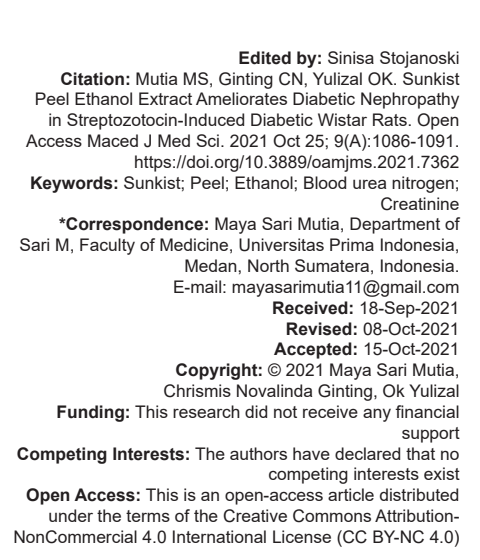

\begin{abstract}
BACKGROUND: Kidney disorders in diabetic patients can gradually fall into end-stage kidney disease (ESKD) which can greatly interfere with the person's quality of life, in developed countries about $50 \%$ of the patients with ESKD are caused by diabetes. On the other hand, various studies on Citrus fruits have been performed to explore its pharmacological benefits.

AIM: This study was aimed to explore the benefits of Sunkist orange peel ethanol extract against diabetic nephropathy in Wistar rats as animals' trial.

METHODS: This study was used 25 rats and was divided into five groups: viz. control, standard, Sunkist Peel Ethanol Extract-I, II, and III (500, 750, and $1500 \mathrm{mg} / \mathrm{kg}$ body weight [BW]). After 28 days of intervention, blood urea nitrogen (BUN) and Creatinine levels were measured in all rats. Meanwhile, data analysis used is parametric statistics in the form of one-way analysis of variance with alternative analysis in the form of the Kruskal-Wallis test.

RESULTS: This study showed that the Sunkist peels ethanol extract significantly decreased BUN $(p<0.05)$ and creatinine $(p<0.05)$ level. The highest dosage of extract did not show a significant difference in BUN level against standard group.

CONCLUSION: Overall, it can be concluded that the Sunkist peel ethanol extract has kidney protection effect against diabetic nephropathy at highest dosage (1500 mg/kg BW).
\end{abstract}

\section{Introduction}

Diabetes mellitus (DM) is a chronic metabolic disorder due to insulin function insufficiency which may due to a lack of insulin production in pancreas. Hence, this condition leads to carbohydrate, lipid, and protein metabolism disorders characterized by high blood glucose levels [1], [2]. Prolonged uncontrolled diabetes may lead to some long-term complications which were retinopathy, nephropathy and neuropathy [3]. On the other hand, diabetes also has high risk to cause some comorbid condition such as heart failure, periphery artery diseases, cerebrovascular disease, obesity, cataract, erection dysfunction, and non-alcoholic fatty liver disease, moreover some communicable disease such as tuberculosis [4].

American Diabetic Association reported that Indonesia was $7^{\text {th }}$ rank in the number of diabetic patients (around 8.5 million patients) in 2013 [5]. Meanwhile, International Diabetes Federation (IDF) also reported that prevalence of diabetic in South-East Asia was 78.3 million people and Indonesia was $7^{\text {th }}$ rank in the number of diabetic patients after China, India, United Stated, Brazil, Russia, and Mexico [6]. Furthermore, estimated incidence rate of DM was 463 million people $(9.3 \%$ of total global population) who were aged between 20 and 79 years old in 2019. This rate was expected to increase until 578 and 700 million people in 2030 and 2045 , respectively. Due to these reasons, it is become important to implicate and develop multi-sectoral strategies to treat diabetes [7].

Kidney disorders in diabetic patients as one of long-term complication is the most common complications of both of diabetes, and fall into end stage kidney disease (ESKD) which is about $50 \%$ of cases in developed countries. Based on IDF data (2019) reports, the percentage of diabetic patients that has chronic kidney disease (CKD) in the UK and US were $25 \%$ and $36 \%$, respectively. Nineteen percent from these cases were CKD with stage 3 or more. Furthermore, decrease in the incidence of CKD in diabetic patients was observed in patients with type 1 diabetes but not in patients with type 2 diabetes [8], [9].

Sunkist from Citrus family is known as a rich source of ascorbic acid, flavonoid, phenolic compounds, and pectin. Some flavonoids in Citrus family were hesperidin, narirutin naringin, and eryocitrin. These compounds have an antidiabetic by inhibiting the activity of glucose-6-phosphate and phosphoenolpyruvate; moreover, others mechanism that responsible for antidiabetic effect were antiperioxidation, inhibition of 
$\alpha$-amylase enzyme, stimulation of insulin secretion, and recovery damage of pancreatic tissue [10].

Previous studies reported that the Sunkist $\left(\mathrm{IC}_{50:} 732 \mu \mathrm{g} / \mathrm{ml}\right)$ had an antioxidant activity by scavenging of DPPH which was more potent than others type of orange like kaffir lime (Citrus hystrix D. C.) with $I_{50}$ value of $1255.07 \mu \mathrm{g} / \mathrm{ml}$, lime (Citrus aurantifolia) with $\mathrm{IC}_{50}$ value of $1631.80 \mu \mathrm{g} / \mathrm{ml}$, pomelo (Citrus maxima Merr) with $\mathrm{IC}_{50}$ value of $1739.72 \mu \mathrm{g} / \mathrm{ml}$ and arrowroot (Citrus nobilis Lour) with $\mathrm{IC}_{50}$ Value of $2192.2 \mu \mathrm{g} / \mathrm{ml}$ [11].

Based on the information above, this study was design to explore the health benefits of Sunkist peels against a long-term complication of diabetes which was diabetic nephropathy, when the incidence of kidney disorders in diabetic patients is quite high in various countries. Kidney disorders in diabetic patients can gradually fall and ended into ESKD which can greatly interfere with the person's quality of life.

\section{Methods}

This study was an experimental study. This study was performed in June 2020 at the Pharmacology Laboratory of the Faculty of Medicine, Universitas Prima Indonesia. This study has been approved by Health Research Ethics Committee from Universitas Prima Indonesia. The materials used in this study were $96 \%$ ethanol, Sunkist peels, sodium carboxymethylcellulose (Na-CMC), Metformin, distilled water, rat pellets, chloroform, Streptozotocin (STZ), and alcohol. This study was used male Wistar rats was the animal trial. The number of sample size was estimated by the Federer formulation, and it was obtained that $n$ higher than 4.75. Hence, this study was used 25 Wistar rats, furthermore these rats were divided into 5 groups, included control, standard, Sunkist Peels Extract-I (500 mg/kg body weight [BW]), II (750 mg/kg BW), and III (1500 mg/kg BW). All rats were acclimatized for 2 weeks before they received the intervention.

The Sunkist was obtained from one of the traditional markets in Medan City, then it was identified at the Medanese Herbarium at FMIPA, University of North Sumatra. Amount of $500 \mathrm{~g}$ Sunkist peel was dried by aerating for 7 days then pulverized to become simplicia powder.

The simplicia powder was extracted by maceration method. Firstly, simplicia powder was macerated by $96 \%$ ethanol as a solvent in a ratio of $1: 10$ for 3 days. The mixture was stirred regularly every day. After 3 days, it was filtered by filter paper, and then the residue was re-macerated with $600 \mathrm{ml}$ of $96 \%$ ethanol for 3 days. The filtered remaceration and maceration were evaporated by rotary evaporator at a temperature of $70^{\circ} \mathrm{C}$ and then followed by concentrated using the oven at $40^{\circ} \mathrm{C}$ until they become thick extracts [12], [13].
Phytochemical screening was performed as qualitative measurement according to a modified Farnsworth method. It consists of the identification of polyphenols, steroids/triterpenoids, glycone, aglycone, anthraquinone, saponins, flavonoids, tannins, and alkaloids [14], [15], [16]

A total of $1 \mathrm{ml}$ of sample was added in $1 \mathrm{ml}$ of $50 \%$ ethanol, and then $0.1 \mathrm{ml}$ of $10 \% \mathrm{AlCl}_{3}$ solution was added. After being incubated for $30 \mathrm{~min}$, absorbance readings were carried out at the maximum wavelength. Determination of total flavonoid content was determined by equation (1) [17].

TFC $=\frac{\text { Equivalent Quersetin Mass }}{\text { Concentration }}$

A milliliter of the sample solution was taken and put into a $10 \mathrm{ml}$ volumetric flask. Add $0.5 \mathrm{ml}$ of FolinDenis reagent and $1 \mathrm{ml}$ of saturated sodium carbonate solution $(35 \%)\left(\mathrm{Na}_{2} \mathrm{CO}_{3}\right)$, then add distilled water up to $10 \mathrm{ml}$. As a blank, distilled water was used instead of the sample. As a standard used tannic acid at various concentrations, total tannin content is expressed in units of $\mathrm{mg}$ equivalent of tannic acid/g sample (mg TAE/g). Determination of total tannin content is determined by equation (2): [18].

TTC $=\frac{\text { Equivalent Tannic Acid Mass }}{\text { Concentration }}$

A total of $0.1 \mathrm{~mL}$ of extract was added with $0.5 \mathrm{~mL}$ of Folin-Ciocalteu reagent. Stir the solution and let stand for $6 \mathrm{~min}$. Add $2.5 \mathrm{~mL}$ of $5 \%$ sodium carbonate solution. Then, the mixture was incubated for $30 \mathrm{~min}$ at room temperature. Absorbance readings were carried out at the maximum wavelength. As a blank, aquadest was used instead of the sample. Gallic acid is used as a standard at various concentrations. Phenolic content is expressed in units of $\mathrm{mg}$ equivalent of gallic acid $/ \mathrm{g}$ sample (mg GAE/g). Determination of total phenolic content was determined by equation (3) [19].

TPC $=\frac{\text { Equivalent Gallic acid Mass }}{\text { Concentration }}$

The Sunkist peels ethanol extract was suspended into the $\mathrm{Na}-\mathrm{CMC}$ to form oral suspension. The oral suspension used $0.5 \%$ sodium carboxymethyl cellulose as vehiculum. It was made by mixing $0.5 \mathrm{~g}$ sodium carboxymethyl cellulose powder into $30 \mathrm{ml}$ hot distilled water in the mortar for $15 \mathrm{~min}$ until it formed a clear phrase. Then, it was grounded until homogeny and dissolved in a volumetric flask by the remaining distilled water to form a vehiculum for extract and standard drugs [12]. After that, the metformin and Sunkist peels extract was suspended into the vehiculum, the $500 \mathrm{mg}, 750 \mathrm{mg}$, and $1500 \mathrm{mg}$ of Sunkist peels extract was suspended into $5 \mathrm{ml}$ of vehiculum to form oral suspension of Sunkist orange peel extract at a dose of $500 \mathrm{mg} / \mathrm{kg} \mathrm{BW}, 750 \mathrm{mg} / \mathrm{kg} \mathrm{BW}$, 
and $1500 \mathrm{mg} / \mathrm{kg} \mathrm{BW}$, respectively [20]. Furthermore, Metformin oral suspension was prepared by mixing

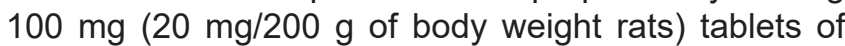
metformin which had been mashed with $0.5 \% \mathrm{Na}-\mathrm{CMC}$ suspension using a $5 \mathrm{ml}$ volumetric flask to the mark.

\section{Treatment}

In the beginning, all rats were induced by a single intraperitoneal injection of STZ (50 mg/kg $\mathrm{BW})$ in $0.1 \mathrm{M}$ citrate buffer $(\mathrm{pH}=4.5) .3$ days after the induction, the fasting blood glucose level was measured by glucometer. Fasting plasma glucose (FPG) was measured in the rat fasted for 10-12 $\mathrm{h}$ before measuring blood glucose levels. Blood samples from all rat were taken from a vein in the tail of rats before induction (FPG 0), $72 \mathrm{~h}$ after induction (FPG 1), and on day 28 (FPG 28) after rats were given Sunkist peels extract and metformin as standard [21].

After 28 days of intervention, all rats were sacrificed by inhalation of chloroform in a closed room, and the blood was collected by cardiac puncture using a $5 \mathrm{ml}$ syringe and 25G-Needle. Moreover, the serum was obtained by centrifugation of obtained blood at 2500 RPM for 10 min [12], [22]. Determination of urea and creatinine levels is based on enzymatic reactions using the Dyasis $®$ reagent kit. The procedure for determining the activity of urea and creatinine catalysts is based on the working procedure of Dyasis ${ }^{\circledR}$.

All data were analyzed descriptively. After that, all data were analyzed distribution data by Shapiro-wilk. If data distribution was normal, then it was expressed as Mean $\pm S D$ and analyzed by one-way analysis of variance (ANOVA). Elseif data distribution was not normal, then it was expressed as Median (Min-Max) and analyzed by Kruskal-Wallis.

\section{Results}

Sunkist that was used for extraction was obtained from a traditional market in the Medan, North Sumatera. The Sunkist was identified in Herbarium Medanesea, Faculty of Mathematics and Natural Sciences, University of North Sumatra, with the following identification results:

Kingdom: Plantae
Division: Spermatophyta
Class: Dicotyledoneae
Order: Rustales
Family: Rutaceae
Genus: Citrus
Species: Citrus sinensis L. Osbeck

Local Name: Sunkist

Based on determination of sample, the Sunkist peel has the scientific name as $C$. sinensis L. Osbeck which comes from Citrus family.

\section{Phytochemicals screening}

The result of phytochemicals screening in Sunkist (C. sinensis L. Osbeck) peels ethanol extract was described in the Table 1.

Table 1: Phytochemicals screening of sunkist (C. sinensis $L$. Osbeck) peels ethanol extract

\begin{tabular}{ll}
\hline Phytochemicals & Result \\
\hline Alkaloid & - \\
Tannin & + \\
Saponin & + \\
Flavonoid & + \\
Triterpenoids & + \\
Steroid & + \\
Glycone & - \\
Aglycone & - \\
Anthraquinone & - \\
Polyphenol & + \\
\hline
\end{tabular}

Based on Table 1, Sunkist ethanol extract has some phytochemicals such as tannin, saponin, flavonoid, triterpenoids, steroid, and polyphenol. However, this test did not determine the phytochemical level. Hence, further investigation was performed to determine the total phenol, tannin, and flavonoid content by spectrophotometry ultraviolet (UV)-Vis. The result of this analysis was described by Table 2 .

Table 2: Determination of total phenolic, tannin, and flavonoid in sunkist peels ethanol extract

\begin{tabular}{ll}
\hline Phenolic compound & Value \\
\hline Total phenolic content (mg GAE/g extract & $9.89 \pm 0.19$ \\
Total tannin content (mg TAE/g extract) & $44.27 \pm 0.29$ \\
Total flavonoid content (mg QE/g extract) & $3.83 \pm 0.00$ \\
\hline
\end{tabular}

Based on the Table 2, it can be seen that the highest level of phenolic compound was tannin (44.27 $\pm 0.29 \mathrm{mg} \mathrm{TAE} / \mathrm{g}$ extract), followed by phenolic (9.89 $\pm 0.19 \mathrm{mg} \mathrm{GAE} / \mathrm{g}$ extract), and the lowest one was flavonoid (3.83 $\pm 0.00 \mathrm{mg} \mathrm{QE} / \mathrm{g}$ extract).

The obtained Sunkist peel ethanol extract then used to evaluate the antidiabetic and kidney protection effects. The antidiabetic and kidney protection effects were evaluated by measuring blood glucose level and kidney function test, respectively. Blood glucose level was measured in 3 different time before induction and 3 days after induction (after induction), and 28 days after the first treatment in all groups (after treatment). Initially, all data was analyzed the distribution data. According to the distribution data, fasting blood glucose before induction and blood urea nitrogen (BUN) level was normal and the remain data includes fasting blood glucose after induction, fasting blood glucose after treatment, and creatinine level was not normal. Hence, the result for fasting blood glucose level among the group compared as described in the Table 3 . 
Table 3: Blood glucose level comparison in treatment groups

\begin{tabular}{llll}
\hline Group & \multicolumn{3}{l}{ Fasting Blood Glucose $(\mathrm{mg} / \mathrm{dl})$} \\
\cline { 2 - 4 } & Before Induction & After Induction & After treatment \\
\hline Standard & $78.80 \pm 2.17$ & $210(195-224)$ & $74(71-76)^{\mathrm{a}}$ \\
Control & $81.80 \pm 4.02$ & $202(196-237)$ & $220(205-250)^{\mathrm{b}}$ \\
Sunkist peels ethanol extract-I & $84.40 \pm 4.51$ & $204(198-219)$ & $86(83-95)^{\mathrm{c}}$ \\
Sunkist peels ethanol extract-II & $84.00 \pm 2.34$ & $218(204-219)$ & $81(78-83)^{\mathrm{d}}$ \\
Sunkist peels ethanol extract-III & $82.80 \pm 3.11$ & $208(182-212)$ & $78(76-78)^{\mathrm{e}}$ \\
Nilai P & $0.103^{*}$ & $0.508^{* *}$ & $<0.05^{* *}$ \\
\hline Difference in superscript in the same column shown significance at $P<0.05$ with post-hoc Test Tukey HSD; \\
"p-value was obtained from one way ANOVA, and data were expressed as mean $\pm \mathrm{SD} ;{ }^{\star *} P$ value was \\
obtained from Kruskal-Wallis Test, and data were expressed as median (min-max).
\end{tabular}

Based on Table 3, the blood glucose level before $(p=0.103)$ and after $(p=0.508)$ induction did not show any significant differences between treatment groups, it was shown by the $p<0.05$. However, the fasting blood glucose level before after induction was higher than the fasting blood glucose level before induction in all treatment groups. Moreover, the fasting blood glucose after treatment significantly decreased after the last measurement (fasting blood glucose after induction) among all groups except the control group, it was shown by the $p<0.05$. After the treatment, the lowest blood glucose level was found in standard group which was $74(71-76) \mathrm{mg} / \mathrm{dl}$, followed by Sunkist peel ethanol extract-III (78 [76-78] mg/dl), I (86 [83-95] $\mathrm{mg} / \mathrm{dl})$, II (81 [78-83] mg/dl), and the highest one was control group which was 220 (205-250) mg/dl. These data showed that the increased of Sunkist peel extract dose would be followed by decrease of fasting blood glucose level.

On the other hand, this study also evaluated kidney function test in all groups. The result for kidney function test among the group compared as described in the Table 4.

Table 4: Kidney function test comparison in treatment groups

\begin{tabular}{lll}
\hline Group & \multicolumn{1}{l}{ Kidney function test } \\
\cline { 2 - 3 } & BUN $(\mathrm{mg} / \mathrm{dl})$ & Creatinine $(\mathrm{mg} / \mathrm{dl})$ \\
\hline Standard & $42.00 \pm 1.58 \mathrm{a}$ & $0.43(0.42-0.46) \mathrm{a}$ \\
Control & $68.20 \pm 3.11 \mathrm{~b}$ & $0.90(0.58-0.92)$ \\
& & $\mathrm{bc}$ \\
Sunkist peels ethanol extract-I & $68.00 \pm 1.58 \mathrm{~b}$ & $0.60(0.51-0.64) \mathrm{b}$ \\
Sunkist peels ethanol extract-II & $39.60 \pm 1.14 \mathrm{a}$ & $0.70(0.67-0.71) \mathrm{c}$ \\
Sunkist peels ethanol extract-III & $31.60 \pm 1.14 \mathrm{c}$ & $0.51(0.48-0.52) \mathrm{d}$ \\
Nilai $\mathrm{P}$ & $<0.05$ & $<0.05$ \\
\hline Difference in superscript in the same column shown significance at $P<0.05$ with $p$ post-hoc Test Tukey HSD; \\
${ }^{*}$ p-value was obtained from one way ANOVA, and data were expressed as mean \pm SD; ${ }^{\star *} P$ value was \\
obtained from Kruskal-Wallis Test, and data were expressed as median (min-max), BUN: Blood urea \\
nitrogen.
\end{tabular}

Based on the Table 4, the BUN and creatinine level were significantly different between treatment groups. Based on the post-hoc test Tukey honestly significant difference, the BUN level from Sunkist peels ethanol extract-III decreased into lower than the standard group and the lower dosage (Sunkist peels ethanol extract-II) showed a similar BUN level against the standard group. Meanwhile the lowest dosage group (Sunkist peel ethanol extract-I) showed a similar BUN level against the control group. On the other hand, creatinine level showed a different result. The standard group was significantly different against other groups, however the lowest and moderate dosage of extract (Sunkist peels ethanol extract-I and II) did not show any significant differences against the control group. The highest dosage showed a different pattern, this group has the lowest creatinine level among the Sunkist peel ethanol extract group, but this level was neither lower nor equivalent to standard group.

\section{Discussion}

STZ has a cytotoxic glucose analogue property. This substance inhibits DNA synthesis in both bacterial and mammalian cells. In bacterial cells, it interacts with specific cytosine moieties which leads to degradation of bacterial DNA. Meanwhile, this substance also acts as a cytotoxic substance to pancreatic $\beta$-cell in mammalian within $70 \mathrm{~h}$ after administration based on the dosage. The cytotoxicity of this substance in mammalian begins to uptake STZ through glucose transporter 2 transporter which causes DNA fragmentation due to nitrosourea moiety in STZ. There major pathways associated with the DNA fragmentation viz. DNA methylation, Nitric oxide production, and free radical generation as hydrogen peroxide [23], [24]. Hence, the STZ may cause DNA methylation, Nitric oxide production, and free radical generation which leads to DNA fragmentation of pancreatic $\beta$-cell and ended by diabetic mellitus.

Nengah et al. (2018) reported that STZ injection dosage of $45 \mathrm{mg} / \mathrm{kg}$ BW could induce hyperglycemic state in $58.4 \%$ of animal trial after 3 days of administration. The hypergylcemic rats suffered 3 different severities of hyperglycemic included mild $(21.5 \%)$, moderate $(11.8 \%)$, and severe $(21.5 \%)$ hyperglycemic state. This hyperglycemic state was due to dysfunction of beta cells pancreas that has selective receptor for STZ, interfere to insulin secretion, and lead to insulin deficiency [25].

Long-term hyperglycaemic state can cause significant kidney tissue change, which lead to kidney failure. This damage can cause several abnormalities in histological structure of kidney tissue included accumulation of extracellular matrix, thickening of the glomerular membrane, and glomerular sclerosis [26].

BUN/Urea is the end product with nitrogen atoms from the catabolism of protein and amino acid, while creatinine is a product of the breakdown of creatine phosphate in muscles and excreted by the kidneys. Urea is a parameter to indirectly measure kidney function because the level of urea in the blood is directly related to the excretory function of the kidneys. Meanwhile, creatinine examination is usually used to diagnose impaired kidney function and measure creatinine phosphate in the blood. Urea and creatinine are good indicators of a normally functioning kidney, and elevated serum indicates renal dysfunction. BUN and serum creatinine are widely accepted and are the most common parameters for assessing renal function [27]. 
Although not as specific as creatinine, urea can also be used as an indicator for assessing clearance kidney, but several factors can affect blood urea levels. Plasma creatinine levels will not increase significantly until extensive renal damage is found [28].

Sunkist peel (C. sinensis (L.) Osbeck) is rich in phenolic compounds that have antidiabetic and antioxidant effects. Based on the phytochemical screening of Sunkist peels ethanol extract, it contains some phytochemical such as alkaloid, tannin, saponin, flavonoid, dan triterpenoids, and steroid. Tannin, flavonoid, and phenol are groups of phenols compound which has hydroxyl group. This study showed that the highest level of these phenols compound was tannin which was $44.27 \pm 0.29 \mathrm{mg}$ TAE$/ g$ extract. Moreover, the lowest one was flavonoid; this compound as Naringin, class of flavonon, was reported to improve hyperglycemic state and maintained expression of some gene that responsible to glucose homeostasis in the body [29].

Some previous study supported the result of this study. Sathiyabama et al. (2018) reported that Sunkist peels extract dosage of $50 \mathrm{mg}$ and $100 \mathrm{mg} /$ $\mathrm{kg}$ BW significantly reduced fasting blood glucose than the control group which received placebo after 28 days of interventions [30]. Ahmed (2018) reported that administration of orange peel extract showed a protective effect against the kidneys through significant improvements in kidney function test. In addition, the administration of this extract also counter oxidative stress effects by evaluation of some antioxidant effect such as glutathione (GSH), lipid peroxidation, and GSH peroxidase [31].

\section{Conclusion}

Overall, it can be concluded that the Sunkist peel ethanol extract has kidney protection effect against diabetic nephropathy at highest dosage $(1500 \mathrm{mg} / \mathrm{kg}$ BW). The highest dosage administration of Sunkist peel ethanol extract significantly reduces fasting blood glucose, BUN, and creatinine level than the control and lower dosage of extract.

\section{References}

1. Malinda H, Rahmawati, Herman H. Gambaran penggunaan obat antidiabetik pada pengobatan pasien diabetes melitus Tipe II rawat jalan di RSUP Dr Wahidin Sudirohusodo Makassar. As-Syifaa. 2015;7(1):93-102. https://doi.org/10.33096/ja.v7i1.26

2. Setyabudi C, Tanda S, Santosa WI, Soetaredjo FE, Kimia JT. Studi in vitro ekstrak kulit jeruk purut untuk aplikasi terapi diabetes melitus. J IIm Widya Tek. 2015;14:15-18.

3. Sah AN, Joshi A, Juyal V, Kumar T. Antidiabetic and hypolipidemic activity of Citrus medica Linn. seed extract in streptozotocin induced diabetic rats. Pharmacogn J. 2011;3(23):80-4. https:// doi.org/10.5530/pj.2011.23.12

4. Classification of Diabetes Mellitus 2019 Classification of Diabetes Mellitus; 2019.

5. Yang W, Dall TM, Halder P, Gallo P, Kowal SL, Hogan PF, et al Economic costs of diabetes in the U.S. in 2012. Diabetes Care. 2013;36(4):1033-46. https://doi.org/102337/dc12-2625 PMid:23468086

6. McCaa RE, McCaa CS, Read DG, Bower JD, Guyton AC Increased plasma aldosterone concentration in response to hemodialysis in nephrectomized man. Circ Res. 1972;31:473-80. https://doi.org/10.1161/01.res.31.4.473

7. Saeedi P, Petersohn I, Salpea P, Malanda B, Karuranga S, Unwin $\mathrm{N}$, et al. Global and regional diabetes prevalence estimates for 2019 and projections for 2030 and 2045: Results from the international diabetes federation diabetes atlas, $9^{\text {th }}$ edition. Diabetes Res Clin Pract. 2019;157:107843. https:// doi.org/10.1016/j.diabres.2019.107843

PMid:31518657

8. Chan S, Chan H, Baboolal K. A review of diabetic kidney disease. J Fam Med. 2017;4(2):1-4.

9. International Diabetes Federation. IDF Diabetes Atlas Ninth. Brussels, Belgium: International Diabetes Federation; 2019. p. 168.

10. Muhtadi, Haryoto, Azizah T, Suhendi A, Yen KH. Antidiabetic and antihypercholesterolemic activities of Citrus sinensis peel: In vivo study. Natl J Physiol Pharm Pharmacol. 2015;5(5):382-5. https://doi.org/10.5455/njppp.2015.5.2807201561

11. Juanda D, Budiana W, Ridwan IM. Penetapan Kadar Total Fenol dan Aktivitas Antioksidan dari Jus Buah Lima Spesies Jeruk (Citrus sp.) [Determination of Total Phenol Levels and Antioxidant Activity of Fruit Juices of Five Citrus Species (Citrus sp.)]. Farm Galen. 2013; 2 (1): 36-42. https://doi.org/10.20473/ jkr.v5i1.19823

12. Mutia MS, Chiuman L. Efek hepatoprotektif ekstrak etano Citrus sinensis $\mathrm{L}$. osbeck pada tikus yang diinduksi parasetamol [[Hepatoprotective effect of Citrus sinensis (L.) osbeck ethanol extract in paracetamol-induced rats]. Maj Kedokt Bandun. 2019; 51 (4): 189-93. https://doi.org/10.15395/mkb.v51n4.1794

13. Kosasih E, Chiuman L, Lister IN, Fachrial E. Hepatoprotective effect of Citrus sinensis peel extract against isoniazid and rifampicin-induced liver injury in wistar rats. Majalah Obat Tradis. 2019;24(3):197-203. https://doi.org/10.22146/mot.45762

14. Widowati W, Fauziah $\mathrm{N}$, Herdiman H, Afni M, Afifah E, Kusuma HS, et al. Antioxidant and anti aging assays of oryza sativa extracts, vanillin and coumaric acid. J Nat Remedies. 2016;16(3):88-99. https://doi.org/10.18311/jnr/2016/7220

15. Widowati W, Rani AP, Hamzah RA, Arumwardana S, Afifah E, Kusuma HS, et al. Antioxidant and antiaging assays of Hibiscus sabdariffa extract and its compounds. Nat Prod Sci. 2017;23(3):192-200. https://doi.org/10.20307/ nps.2017.23.3.192

16. Widowati W, Widya Janeva B, Nadya S, Amalia A Arumwardana S, Kusuma HS, et al. Antioxidant and antiaging activities of Jasminum sambac extract, and its compounds. J Rep Pharm Sci. 2018;7(3):270-85.

17. Louis H, Maitera ON, Boro G, Barminas JT. Determination of total phenolic content and some selected metals in extracts of Moringa oleifera, Cassia tora, Ocimum gratissimum, Vernonia baldwinii and Telfairia occidentalis plant leaves. World News Nat Sci. 2017;11:11-8. Available from: http://www.yadda.icm. edu.pl/yadda/element/bwmeta1.element.agro-3d9f3320-334f4316-a4c4-6eef880a2b47/c/wnofns-11-2017-11-18-2.pdf. [Last 
accessed 2021 Sep 01]

18. Septiana D. Analisis kadar alkaloid dan tanin tumbuhan beluntas (Pluchea indica Less.) pada lahan salin di desa asingi kecamatan tinanggea dan non salin di desa lambodijaya kecamatan lalembuu sulawesi tenggara. Biowallacea. 2014;1(2):82-9. Available from: http://www.ojs.uho.ac.id/index. $\mathrm{php} /$ wallacea/article/download/133/92 [Last accessed $2021 \mathrm{Sep}$ 01]

19. Bouyahya A, Moussaoui N, Abrini J, Bakri Y, Dakka N. Determination of phenolic contents, antioxidant and antibacterial activities of strawberry tree (Arbutus unedo L.) leaf extracts. $\mathrm{Br}$ Biotechnol J. 2016;14(3):1-10. https://doi.org/10.9734/ bbj/2016/26488

20. Maheshwari H, Satyaningtijas AS, Harlina E, Ningsih UC, Effendi M, Mustofa MA, et al. The role of fennel infusion on estrous cycle and follicles development of white rats. J IImu Kefarmasian Indones. 2016;14(1):19-25.

21. Zubaidah E, Afgani CA, Kalsum U, Srianta I, Blanc PJ. Comparison of in vivo antidiabetes activity of snake fruit Kombucha, black tea Kombucha and metformin. Biocatal Agric Biotechnol. 2019;17:465-9. https://doi.org/10.1016/j. bcab.2018.12.026

22. Ongko NX, Chiuman L, Ginting CN. Effect of white turmeric rhizome extract (Curcuma zedoaria) on testis histology of male wistar rat. Am Sci Res J Eng Technol Sci. 2019;55(1):69-74.

23. Eleazu CO, Eleazu KC, Chukwuma S, Essien UN. Review of the mechanism of cell death resulting from streptozotocin challenge in experimental animals, its practical use and potential risk to humans. J Diabetes Metab Disord. 2013;12(1):60. https://doi. org/10.1186/2251-6581-12-60 PMid:24364898

24. Alotaibi MR, Fatani AJ, Almnaizel AT, Ahmed MM, Abuohashish HM, Al-Rejaie SS. In vivo assessment of combined effects of glibenclamide and losartan in diabetic rats. Med Princ Pract. 2019;28(2):178-85. https://doi. org/10.1159/000496104 PMid:30537701

25. Saputra NT, Suartha IN, Dharmayudha AA. Agen diabetagonik streptozotocin untuk membuat tikus putih jantan diabetes mellitus [Streptozotocin diabetagonic agent for inducing diabetes mellitus in male rats]. 2018;10(2):116. https://doi. org/10.24843/bulvet.2018.v10.i02.p02

26. Worotikan RV, Tuju EA, Kawuwung F. Analisa efektivitas antidiabetes ekstrak etanol buah andaliman (Zanthoxylum acanthopodium DC) pada histopatologi ginjal tikus putih (Rattus norvegicus) yang diinduksi alloksan [Analysis of the antidiabetic effectiveness of the lemon pepper (Zanthoxylum acanthopodium DC) ethanol extract of on the histopathology of the kidneys of Alloxan-Induced rats (Rattus norvegicus)]. J Sains Mat Edukasi. 2017;5(1):29-37. https://doi.org/10.15562/ism.v11i1.666

27. Pandya D, Nagrajappa AK, Ravi KS. Assessment and correlation of urea and creatinine levels in saliva and serum of patients with chronic kidney disease, diabetes and hypertension-a research study. J Clin Diagn Res. 2016;10(10):ZC58-62. https://doi. org/10.7860/JCDR/2016/20294.8651

PMid:27891460

28. Salazar JH. Overview of urea and creatinine. Lab Med. 2014;45(1):e19-20.

29. Ahmed OM, Hassan MA, Abdel-Twab SM, Abdel Azeem MN. Navel orange peel hydroethanolic extract, naringin and naringenin have anti-diabetic potentials in Type 2 diabetic rats. Biomed Pharmacother. 2017;94:197-205. https://doi. org/10.1016/j.biopha.2017.07.094 PMid:28759757

30. Sathiyabama RG, Rajiv Gandhi G, Denadai M, Sridharan G, Jothi $G$, Sasikumar $P$, et al. Evidence of insulin-dependent signalling mechanisms produced by Citrus sinensis (L.) Osbeck fruit peel in an insulin resistant diabetic animal model. Food Chem Toxicol. 2018;116(B):86-99. https://doi.org/10.1016/j. fct.2018.03.050

PMid:29614383

31. Ahmed RA. Hepatoprotective and antiapoptotic role of aged black garlic against hepatotoxicity induced by cyclophosphamide. J Basic Appl Zool. 2018;79(8):1-8. https://doi.org/10.1186/ s41936-018-0017-7 